\title{
Pegylated-Interferon and Ribavirin for Chronic Hepatitis C Virus Infection in Decompensated Cirrhotics Awaiting Liver Transplantation
}

\author{
B.E. Annicchiarico ${ }^{*}, 1$, M. Siciliano ${ }^{1}$, A.W. Avolio ${ }^{2}$, S. Agnes ${ }^{2}$ and A. Gasbarrini ${ }^{1}$ \\ ${ }^{I}$ Department of Internal Medicine; ${ }^{2}$ Department of Surgery, Transplantation Service; Università Cattolica del Sacro \\ Cuore, Rome, Italy
}

\begin{abstract}
Sustained virologic response (SVR) to the antiviral therapy for chronic hepatitis C virus infection before liver transplantation (LT) can prevent graft infection. Pegylated (PEG)- interferon (IFN) may ameliorate the SVR, improving the risk-to-benefit ratio of antiviral therapy in cirrhotics awaiting LT. From January 2001 to March 2009, 21 HCVinfected cirrhotics eligible for LT were treated with PEG-IFN alpha- $2 \mathrm{~b}(1.5 \mu \mathrm{g} / \mathrm{kg}$ weight $/$ week) and ribavirin (800-1200 $\mathrm{mg} /$ day). Mean age was $53.7 \pm 7.9$ years. There were $11 \mathrm{men}$. Eleven had genotype 1b. Child-Pugh score was 9.5 \pm 1.2 , Model for End-Stage Liver Disease score 16.6 \pm 1.8 . Besides virologic failure, full dosage and planned length of therapy were tolerated in 5 patients $(23.8 \%)$. Adverse events occurred in all patients, life-threatening in $9(42.9 \%)$. No patient died during treatment. Adverse events caused treatment withdrawal in 11 patients (52.4\%), ribavirin and/or PEG-IFN reduction in 7 (33.3\%). On an intention-to-treat basis, SVR was obtained in 4 patients (19.0\%). None of the genotype 1 or 3 patients obtained SVR; $50.0 \%$ of genotype 2 patients obtained SVR. All patients with SVR experienced rapid virological response (RVR). Six patients (three nonresponders, two relapsers, one sustained responder) were transplanted; six died; four are awaiting LT; two are under evaluation for listening; three refused LT. The risk-to-benefit ratio is against treatment with PEG-IFN and ribavirin of severely decompensated genotype 1 cirrhotics. In contrast, antiviral therapy is probably beneficial in genotype 2 subjects, due to an expected SVR rate of $50 \%$. However, one must carefully consider the high risk for severe adverse events.
\end{abstract}

Keywords: Antiviral therapy, hepatitis C virus infection, liver cirrhosis, decompensated cirrhosis, liver transplantation.

\section{INTRODUCTION}

Chronic hepatitis $\mathrm{C}$ virus (HCV) infection represents the most common indication for liver transplantation (LT) in the Western world [1]. After LT, HCV reinfection occurs in all patients with pretransplant viremia. Although recurrent $\mathrm{HCV}$ infection has a variable course, it leads to cirrhosis in 10 to $25 \%$ of transplant recipients within 5 to 10 years, substantially reducing the benefits of LT [2].

Sustained serum HCV clearance by antiviral therapy, either before or after LT, can prevent graft infection or avoid the establishment of a chronic infection.

Current therapy for chronic HCV infection with pegylated (PEG)-interferon (IFN) and ribavirin (RBV) allows persistent eradication of HCV from the serum in more than half of the treated patients $[3,4]$. Although this therapy is widely accepted for patients with advanced fibrosis or earlycompensated cirrhosis, its feasibility in decompensated cirrhotics is still debated [5]. In studies on therapy with IFN and RBV in patients with decompensated liver disease, a reduced rate of serum HCV-RNA clearance is associated with an increased risk of severe, life-threatening adverse events [6-12]. However, the use of PEG-IFN instead of IFN may ameliorate the virologic response, improving the riskto-benefit ratio of antiviral therapy in cirrhotic patients awaiting LT.

*Address correspondence to this author at the Department of Internal Medicine, Università Cattolica del Sacro Cuore, Largo F. Vito 1, +3900168 Roma, Italy; Tel: +390630155600; Fax: +390635500486; E-mail: terapiamedica@tin.it
In our study, we evaluated the efficacy and safety of current standard antiviral therapy for chronic HCV infection in cirrhotic patients listed for LT at our Institution.

\section{MATERIALS AND METHODOLOGY}

From January 2001 to March 2009, all consecutive cirrhotic patients with chronic HCV infection eligible for $\mathrm{LT}$ at our Institution were evaluated for antiviral therapy. Inclusion criteria were: total bilirubin $<5.0 \mathrm{mg} / \mathrm{dL}$, albumin $>2.0 \mathrm{~g} / \mathrm{dL}$, international normalized ratio $<1.7$, platelet (PLT) count $>40,000 / \mu \mathrm{L}$, absolute neutrophil (NEU) count $>1,000 / \mu \mathrm{L}$, hemoglobin $(\mathrm{Hb})>10.0 \mathrm{~g} / \mathrm{dL}$, creatinine $<1.5 \mathrm{mg} / \mathrm{dL}$, esophageal varices not at risk of bleeding, Child-TurcottePugh (CTP) score $<12$, Model for End-Stage Liver Disease (MELD) score <20. Immunological, cardiac, pulmonary, metabolic, and psychiatric contraindications to IFN e RBV, viral co-infections, hepatocellular carcinoma (HCC), recurrent bacterial infections, previous/present hepatic encephalopathy (HE), refractory ascites were considered as exclusion criteria.

After obtaining informed consent, all eligible patients underwent to antiviral therapy with subcutaneous PEG-IFN alpha-2b (PEG-Intron, Schering-Plough, Brussels, Belgium; $1.5 \mu \mathrm{g} / \mathrm{kg}$ body weight $/$ week) and oral RBV (Rebetol, Schering-Plough, Brussels, Belgium; $800 \mathrm{mg} /$ day for HCV genotype 2 or 3 and 1000 or $1200 \mathrm{mg}$ based on body weight $<$ or $\geq 75 \mathrm{~kg}$ for HCV genotype 1 or 4 ). The length of antiviral therapy was 24 weeks for HCV genotype 2 or 3 and 48 weeks for HCV genotype 1 or 4 (5). Erythropoietin (Eprex, 
Janssen-Cilag SpA, Milan, Italy) and granulocyte colonystimulating factor (Myelostim 34, Italfarmaco SpA, Milan, Italy) were employed respectively in presence of $\mathrm{Hb}<10.0$ $\mathrm{g} / \mathrm{dL}$ or absolute NEU count $<750 / \mu \mathrm{L}$.

Quantitative HCV-RNA test (Cobas Amplicor HCV Monitor v2.0, Roche Diagnostic; limit of sensitivity 600 $\mathrm{IU} / \mathrm{mL}$ ) and $\mathrm{HCV}$ genotyping (Innolipa HCV, Innogenetics) were performed in all patients before the antiviral therapy. Response to treatment was evaluated by a quantitative HCVRNA test. A qualitative HCV-RNA test (Cobas Amplicor HCV v2.0, Roche Diagnostic; limit of sensitivity $50 \mathrm{IU} / \mathrm{mL}$ ) was performed when serum virus was undetectable by the quantitative test.

Rapid virologic response (RVR) was defined as undetectable HCV-RNA at week 4 of therapy; early virologic response (EVR) as a $\geq 2 \log$ drop or loss of HCV-RNA at week 12 of therapy. Patients who did not experience EVR were considered as non-responder (NR) and discontinued therapy. End-of-treatment response (ETR) was defined as undetectable HCV-RNA at the end of therapy; sustained virologic response (SVR) as undetectable HCV-RNA 24 weeks after the end of therapy. Patients were considered to have a virologic relapse (REL) when HCV-RNA reappeared while still on therapy or after the end of therapy (5). Virologic tests were performed at week 4 and at week 12 of therapy in all patients. Thereafter, HCV-RNA test was performed every 12 weeks until the end of therapy in all patients with EVR and 24 weeks after the end of therapy in those with ETR.

All patients had weekly clinical and laboratory controls. Clinical side effects or abnormalities in liver function tests brought to reduction or withdrawal of therapy according to the judgement of the attending physician. A fall of the absolute NEU count $<750 / \mu \mathrm{L}$ or of the PLT count $<30,000 / \mu \mathrm{L}$ brought to reduction of PEG-IFN. A fall of $\mathrm{Hb}$ $<10.0 \mathrm{~g} / \mathrm{dL}$ brought to reduction of RBV. A fall of the absolute NEU count $<500 / \mu \mathrm{L}$ or of the PLT count $<20,000 / \mu \mathrm{L}$ brought to treatment withdrawal. A fall of $\mathrm{Hb}$ $<8.0 \mathrm{~g} / \mathrm{dL}$ brought to RBV withdrawal. For mild infections dose modification was not considered; for moderate or major infections the drug dose was respectively reduced or discontinued.

\section{RESULTS}

Twenty-one HCV-infected cirrhotic patients eligible for LT consented to antiviral treatment. Baseline characteristics of these patients are shown in Table $\mathbf{1}$.

Treatment for HCC was performed with radiofrequency ablation or transarterial chemioembolization in three patients during 12 months prior to the antiviral therapy. Computed tomography performed immediately before the beginning of the antiviral therapy did not show HCC recurrence.

Besides virologic failure, full dosage and planned length of therapy were tolerated in $5(23.8 \%)$ patients. The mean duration of therapy in genotype 1 and in genotype 2-3 patients was respectively: $9.7 \pm 3.9$ and $15.7 \pm 9.7$ weeks. No patient sustained a course of therapy longer than 24 weeks.

Adverse events occurred in all patients. Type and number of significant adverse events registered during therapy are shown in Table 2.
Table 1. Baseline Characteristics of the Patients Submitted to Antiviral Therapy

\begin{tabular}{|c|c|}
\hline Variables & (N= 21) \\
\hline \hline Male Sex & $11(52.4)$ \\
\hline Age, $y$ & $53.7 \pm 7.9 ; 37-63$ \\
\hline Naïve & $10(47.6)$ \\
\hline HCV Genotype & $11(52.4)$ \\
\hline 1 & $8(38.1)$ \\
\hline 2 & $2(9.5)$ \\
\hline 3 & $5.72 \pm 5.66 ; 4.67-6.28$ \\
\hline HCV-RNA, $\log 10 \mathrm{IU} / \mathrm{mL}$ & $9.5 \pm 1.2 ; 8-12$ \\
\hline CTP Score & $16.6 \pm 1.8 ; 14-20$ \\
\hline MELD Score & $12.0 \pm 0.9 ; 10.0-13.0$ \\
\hline Hemoglobin, $\mathrm{g} / \mathrm{dL}$ & $70 \pm 14 ; 46-95$ \\
\hline Plateletsx $10^{3} / \mu \mathrm{L}$ & $1.8 \pm 0.4 ; 1.2-2.8$ \\
\hline Neutrophils $x 10^{3} / \mu \mathrm{L}$ & $14(66.7)$ \\
\hline Varices & \\
\hline Q & \\
\hline
\end{tabular}

Qualitative variables are presented as $n(\%)$ and quantitative variables as mean $\pm \mathrm{SD}$ (range).

Table 2. Adverse Events during Antiviral Therapy

\begin{tabular}{|c|c|}
\hline Adverse Events & \\
\hline $\begin{array}{c}\text { Intolerance (Severe Fatigue, } \\
\text { Prolonged Flu-like Symptoms, } \\
\text { Depression) }\end{array}$ & 3 \\
\hline $\mathrm{Hb}<8.5 \mathrm{~g} / \mathrm{dL}$ & 3 \\
\hline PLT count $<35,000 / \mu \mathrm{L}$ & 9 \\
\hline NEU count $<650 / \mu \mathrm{L}$ & 8 \\
\hline Moderate Infection & $\begin{array}{l}2 \text { (one hemorrhagic cystitis; one } \\
\text { acute bronchitis) }\end{array}$ \\
\hline Major Infection & $\begin{array}{l}4 \text { (two pneumonia; one pelvic } \\
\text { infection; one spontaneous } \\
\text { bacterial peritonitis) }\end{array}$ \\
\hline Refractory Ascites & 1 \\
\hline Hepatic Encephalopathy grade III & 3 \\
\hline Variceal Bleeding & 2 \\
\hline Hepatocellular Carcinoma & 1 \\
\hline
\end{tabular}

Minimal-to-moderate adverse events such as mild fatigue, insomnia, transient flu-like symptoms, hypothyroidism, minimal ascites, mild infections, mild anemia, neutropenia, and thrombocytopenia were considered unsignificant and are not reported. Severe life-threatening adverse events were registered in 9 patients (42.9\%). No patient died during antiviral treatment.

Adverse events caused treatment withdrawal in 11 patients $(52.4 \%)$ between $2^{\text {nd }}$ to $16^{\text {th }}$ week of therapy and RBV and/or PEG-IFN dose reduction in 7 patients $(33.3 \%)$ between the $1^{\text {st }}$ and $24^{\text {th }}$ week of therapy. 
On an intention-to-treat basis, SVR was obtained in 4 patients $(19.0 \%)$. RVR was obtained in 5 patients $(23.8 \%)$, EVR in 8 patients $(38.1 \%)$. Only four patients, all infected by genotype 2 , completed the planned course of antiviral therapy and had ETR (19.0\%). None of the genotype 1 or 3 patients obtained SVR. Among the HCV genotype 2 subjects, 4 patients $(50.0 \%)$ obtained SVR. All patients who obtained SVR experienced RVR. Only one patient (HCV genotype 3) with RVR relapsed after the interruption of antiviral therapy at the $16^{\text {th }}$ week due to variceal bleeding.

Six patients (three nonresponders, two relapsers, and one sustained responder) were transplanted between $7^{\text {th }}$ and $40^{\text {th }}$ month after the end of antiviral therapy. Six patients died between $3^{\text {rd }}$ and $37^{\text {th }}$ month after the end of antiviral therapy. Four patients are awaiting LT. Two patients are under evaluation for listening. Three patients refused LT.

\section{DISCUSSION}

Available data about IFN and RBV treatment of HCV infection in severely decompensated liver cirrhosis show a low rate of virologic response in front of many life-threatening drug-induced adverse events [6-12]. However, HCV clearance in decompensated cirrhotics may halt disease progression, delaying or avoiding the need for $\mathrm{LT}$, and may reduce or eliminate the risk of recurrent $\mathrm{HCV}$ infection in the transplanted liver, improving graft and patient survival [2].

The use of PEG-IFN may ameliorate virologic response, improving the risk-to-benefit ratio of antiviral therapy. In our study, standard PEG-IFN and RBV combination therapy in $\mathrm{HCV}$-infected liver cirrhotics awaiting LT produced significant side effects in all patients and severe life-threatening adverse events in about $40.0 \%$ of them. The rate of SVR was very low (19.0\%). RVR and HCV genotype 2 were the most strong predictors of SVR. None of subjects infected by HCV genotype 1 obtained SVR. Such a dismal result may be ascribed to the large proportion of patients forced to have prolonged dose reduction or treatment withdrawal by adverse events. The better result obtained in patients infected by HCV genotype 2 was probably due to the fact that even a suboptimal treatment can eradicate this genotype from the serum.

\section{CONCLUSION}

The risk-to-benefit ratio is strongly against treatment with PEG-IFN and RBV of severely decompensated cirrhotics infected by HCV genotype 1. In contrast, antiviral therapy is probably beneficial in HCV genotype 2-infected subjects, due to an expected SVR rate of about $50 \%$. However, one must carefully consider the high risk for severe adverse events.

\section{REFERENCES}

[1] Williams R. Global challenges in liver disease. Hepatology 2006; 44: 521-6.

[2] Terrault NA, Berenguer M. Treating hepatitis C infection in liver transplant recipients. Liver Transplant 2006; 12: 1192-204.

[3] Manns MP, McHutchison JG, Gordon SC, et al. Peginterferon alfa$2 \mathrm{~b}$ plus ribavirin compared with interferon alfa- $2 \mathrm{~b}$ plus ribavirin for initial treatment of chronic hepatitis C: a randomised trial. Lancet 2001; 358: 958-65.

[4] Fried MW, Shiffman ML, Reddy KR, et al. Peginterferon alfa-2a plus ribavirin for chronic hepatitis $\mathrm{C}$ virus infection. $\mathrm{N}$ Engl J Med 2002; 347: 975-82.

[5] Ghany MG, Strader DB, Thomas DL, Seeff BS. AASLD Practice guidelines. Diagnosis, management, and treatment of hepatitis C: an update. Hepatology 2009; 4: 1335-74.

[6] Everson GT. Treatment of chronic hepatitis $\mathrm{C}$ in patients with decompensated cirrhosis. Rev Gastroenterol Disord 2004; 4(Suppl 1): $\mathrm{S} 31-8$.

[7] Everson GT, Trotter J, Forman L, et al. Treatment of advanced hepatitis $\mathrm{C}$ with a low accelerating dosage regimen of antiviral therapy. Hepatology 2005; 42: 255-62.

[8] Forns X, Garcia-Retortillo M, Serrano T, et al. Antiviral therapy of patients with decompensated cirrhosis to prevent recurrence of hepatitis C after liver transplantation. J Hepatol 2003; 39: 389-96.

[9] Crippin JS, McCashland T, Terrault N, Sheiner P, Charlton MR. A pilot study of the tolerability and efficacy of antiviral therapy in hepatitis $\mathrm{C}$ virus-infected patients awaiting liver transplantation. Liver Transplant 2002; 8: 350-5.

[10] Thomas RM, Brems JJ, Guzman-Hartman G, et al. Infection with chronic hepatitis $\mathrm{C}$ virus and liver transplantation: a role for interferon therapy before transplantation. Liver Transplant 2003; 9 : 905-15.

[11] Iacobellis A, Siciliano M, Perri F, et al. Peginterferon alfa-2b and ribavirin in patients with hepatitis $\mathrm{C}$ virus and decompensated cirrhosis: a controlled study. J Hepatol 2007; 46: 206-12.

[12] Annicchiarico BE, Siciliano M, Avolio AW, et al. Treatment of chronic hepatitis $\mathrm{C}$ virus infection with pegylated interferon and ribavirin in cirrhotic patients awaiting liver transplantation. Transplant Proc 2008; 40: 1918-20. 